\title{
ANALISIS JAWABAN SISWA MENURUT TIPE KEPRIBADIAN DALAM MENYELESAIKAN SOAL CERITA MATERI BANGUN RUANG
}

\author{
${ }^{1}$ Esteria Nomiana, ${ }^{2}$ Agung Hartoyo, ${ }^{3}$ Dede Suratman \\ ${ }^{1,2,3}$ Pendidikan Matematika FKIP Universitas Tanjungpura, Pontianak, Indonesia \\ Email: esterianomiana@gmail.com
}

\begin{abstract}
This studyaims to describe the answer errors of students with extrovert-introvert personalities when solving story problems with material blocks and cubes based on the newman procedure. This type of research is a qualitative descriptif study. The subject in this study involved 29 junior high school students. The object of this research is the extrovert-introvert personality student's answer errors in solving block and cube story problems based on the newman procedure. Data collection techniques used were distributing personality questionnaires and test questions on blocks and cubes, as well as direct communication (interview).The results of the personality questionnaire taken were 3 students with high extrovert personalitiesand 3 students with high introvert personalities Analysis framework to reveal errors using newman procedure While the analysis technique uses qualitative data analysis of miles and huberman. The results of the errors made by students in this study were reading errors $(R)$, misunderdtsnding problems $(C)$,transgormation errors $(P)$, and final answer errors $(E)$.This mistakes made by extrovert-introverted students were mostly transformation errors $(T)$, processing skills errors $(P)$, and final answer errors $(E)$.
\end{abstract}

Keywords: Errors Answer, Extrovert-Introvert Persobality, Procedure Newman

\section{Pendahuluan}

Matematika adalah ilmu pengetahuan yang mempunyai pengaruh pada perkembangan zaman, dimulai dari bidang ekonomi, teknologi, sosial dan bidang lainnya. Selain sebagai pengaruh pada perkembangan zaman, matematika juga dikenal sebagai ilmu dasar bagi ilmu lain seperti fisika, biologi, komputer dan lain-lain. Sehingga matematika bukan hanya sekedar angka, simbol dan rumus yang tidak menyangkut dalam dunia nyata melainkan matematika sangat dibutuhkan dalam kehidupan yang akan datang. Hal ini didukung oleh pendapat Court (dalam Hardi, 2016:117); (Hartoyo, 2012), yang menyatakan bahwa matematika memiliki suatu keterkaitan yang cukup kuat dengan lingkungan sekitar atau kehidupan sosial manusia, sehingga matematika menjadi alat yang sangat penting bagi kehidupan manusia.

Seperti halnya juga tertuang dalam Kurikulum 2013 yang sesuai dengan pemendikbut Nomor 22 Tahun 2016 dimana tujuan pembelajaran matematikameliputi :(1) memahami konsep matematika,mendeskripsikan bagaimana keterkaitan antar konsep matematika dan menerapkan konsep atau logaritma secara efesien, luwes, akurat, dan tepat dalam memecahkan masalah; (2) menalar pola sifat dari matematika, mengembangkan atau memanipulasi matematika dalam menyusun argumen,merumuskan, atau mendeskripsikan argumen dan pernyataan matematika; (3) memecahkan masalah matematika yang meliputi kemampuan memahami masalah, menyusun model penyelesaian matematika, menyelesaikan model matematika dan memberikan solusi yang tepat; (4) mengkomunikasikan argumen atau gagasan dengan diagram, tabel, simbol, atau medialainnya agar dapat memperjelas permasalahan atau keadaan. Sehingga salah satunya adalah kemampuan pemecahan masalah. 
Pada peserta didik tingkat sekolah menengah pertama, pemecahan masalah bentuk soal cerita yang berkaitan dengan materi bangun ruang merupakan materi yang cukup sulit bagi peserta didik.dalam proses pengerjaanya. Pada proses pengerjaan soal cerita siswa harus mampu mengusai atau memahaminya dengan sebaik mungkin, berbeda dengan soal matematika berbentuk hitungan peserta didik hanya memerlukan skill berhitungnya saja. Hal inilah yang sering kali menyebakan peserta didik hasil belajar peserta didik menjadi rendah, tentunya jika hasil belajar peserta didik menjadi sendah tentu ada kesalahan-kesalahan yang dialami oleh peserta didik saat proses pengerjaaan soal.

Jika dilihat dari hasil wawancara yang dilakukan peneliti dengan salah satu guru matematika di SMPN 12 Pontianak terdapat sebagain peserta didik hasil belajarnya rendah mereka sering melakukan kesalahan baik pada proses pemahaman terhadap soal, cara mereka memodelkan matematika, bahkan mereka paling banyak melakukan kesalahan pada proses perhitungan atau proses skill pada materi bangun ruang. Berikut dilampirkan tabel hasil ulangan peserta didik di kelas VIII SMPN 12 Pontianak pada materi bangun ruang :

Tabel 1.1 Data Hasil Ulangan Peserta didik SMPN 12 Pontianak

\begin{tabular}{|c|c|c|c|}
\hline $\begin{array}{c}\text { Nilai } \\
\text { MID }\end{array}$ & $\begin{array}{c}\text { Jumlah } \\
\text { Peserta } \\
\text { Didik }\end{array}$ & Persentase & Keterangan \\
\hline$\geq 75$ & 6 & $20 \%$ & Tuntas \\
\hline$<75$ & 24 & $80 \%$ & $\begin{array}{c}\text { Tidak } \\
\text { Tuntas }\end{array}$ \\
\hline Total & 30 & $100 \%$ & \\
\hline
\end{tabular}

Abdurahaman (2012:213) supaya peserta didik dapat terbantu ketika mereka mengalami kesulitan belajar matematika, maka seorang pengajar harus mengetahui apa saja yang menyebabkan peserta didik hasil belajarnya menjadi rendah saat menyelesaikan soal matematika. Maka dari itu hal-hal yang menyebabkan peserta didik melakukan kesalahan harus diketahui oleh seorang pengajar. Ada beberapa hal yang seorang pengajar mengetahui hal apa yang menyebabkan kesalahan belajar pada peserta didik yaitu salah satunya menganalisis hasil pengerjaan peserta didik pada sebuah tes matematika yang telah diberikan pada materi tersebut (Saputro et al., 2015).

Tugas utama sebagai pengajar bukan hanya mengkaji mengenai kesalahan yang dialami peserta didik pada masalah matematika, akan tetapi tugas pengajar hendaknya harus mengetahui apa penyebab masalah yang dialami peserta didik dalam matematika, salah satunya dengan cara mengetahui karakteristik peserta didik. Menurut Sardiman (dalam Ramalisa2013:42) karakteristik peserta didik yang dapat mempengaruhi kegiatan belajar peserta didik antara lain: latar belakang, taraf pengetahuan, gaya belajar, proses berfikir, usia, kronologi, kepribadian, tingkat kematangan, keyakinan, lingkungan, sosial ekonomi dan sebagainya. Dari pendapat tersebut terlihat bahwa salah satu karakteristik peserta didik yang dapat mempengaruhi belajar adalah kepribadian.

Menurut Zaman dan Abdilah (2009:20); (Sarwono et al., 2017), meembagi tipe kepribadian menjadi empat kencenderungan kepribadian manusia. Zaman dan Abdilah (2009:20) membagi tipe kepribadian menjadi menjadi dua, yaitu ekstrovert dan introvert.Secara umum kepribadian ekstrovert memiliki ciri "tidak suka dengan kegiatan yang membutuhkan waktu yang lama dan bertidak lebih dahulu dari pada merenungkan 
sedangkan kepribadian introvert memiliki ciri nyaman dengan kegiatan yang membutuhkan waktu yang lama dan merenungkan terlebih dahulu baru bertindak" (Zaman dan Abdilah, 2009:23).Dengan menyadari perbedaan kondisi pada masingmasing peserta didik, maka pengajar dapat mengetahui kesalahan-kesalahan yang dialami peserta didik dalam menyelesaikan soal cerita pada peserta didik yang memiliki ciri kepribadian ekstrovert dan introvert.

Prosedur Newman adalah salah satu metode yang dapat digunakan untuk menganalisis kesalahan-kesalahan yang dilakukan peserta didik. Pada metode ini Anne Newman menyarankan lima kegiatan spesifik sebagai hal-hal yang penting untuk membantu menemukan dimana kesalahan yang terjadi pada pekerjaan peserta didik ketika menyelesaikan suatu pemecahan masalah berbentuk soal cerita. Prosedur Newman dipilihkarena prosedur ini merupakan metode diagnostik yang dikembangkan Newman dan digunakan untuk mengidentifikasi katagorikesalahan terhadap jawaban dari sebuah tes uraian. Tahapan kesalahan dalam menyelesaikan soal cerita menurut prosedur Newman (Prakatipong dan Nakamura, 2006:114); (Ulya, 2020), yaitu kesalahan membaca masalah, kesalahan memahami masalah, kesalahan tranformasi, kesalahan keterampilan proses dan kesalahan penulisan jawaban.

\section{Metode Penelitian}

Penelitian ini menggunakan metode kualitatif dengan pendekatan deskritif.Pendeskripsian ini ditelusuri dengan pengamatan langsung, yaitu menganalisis hasil tes yang dikerjakan oleh subjek penelitian yaitu peserta didik dengan tipe kepribadian esktrovert-introvert.Bentuk penelitian yang digunakan adalah survey. Objek penelitian ini adalah analisis jawaban peserta didik dengan kepribadian ekstrovertintrovert berdasarkan prosedur newman. Subjek dalam penelitian ini adalah siswa kelas IX SMPN 12 Pontianak diambil satu kelas yaitu kelas 9 G. Dari satu kelas tersebut diambil 3 ekstrovert dan 3 introvert yang paling tinggi berdasarkan hasil angket yang telah diberikan.

Pada prosedur penelitian yang yang paling utama dilakukan adalah melakukan persiapan pada tahapan pelaksaan, kemudia setelah semuanya sudah disiapkan langkah selanjutnya melaksanaan seluruh kegiatan yang sudah disiapkan, dan bagian terakhir adalah membuat laporan hasil penelitian yang telah dilakukan. Adapun kegiatan yang dilakukan pada tahap persiapan antara lain : melakukan pra riset di SMPN 12 Pontianak, melakukan wawancara dengan salah satu guru matematika dikelas 9G, menyusun desain penelitian, membuat istrumen yang disusun berdasrkan kurikulum, melakukan validasi terhadap instrument penelitian yang dilakukan oleh dosen Pendidikan matematika dan guru mata pelajaran, melakukan uji coba instrument penelitian kepada siswa yang pernah mempelajari materi tersebut, dan menganalisis data hasil uji coba instrument penelitian untuk menentukan validitas butir soal dan reabilitas. Pada tahap pelaksanaan kegiatan yangh dilakukan antara lain : memberikan soal tes angket kepribadian kepada peserta didik di SMPN 12 Pontianak kelas 9G; melakukan pemilihan subjek dengan melihat hasil angket tertinggi 3 ekstrovert dan 3 introvert; memberikan soal tes balok dan kubus kepada 3 peserta didik dengan kepribadian ekstrovert tinggi dan 3 peserta didik introvert tinggi; menganalisis hasil jawaban tes dari ke-6 peserta didik tersebut 
berdasarkan prosedur newman. Sedangkan kegiatan yang dilakukan pada tahap akhir antara lain : membuat kesimpulan untuk menjawab rumusan masalah dan menyusun laporan penelitian.

\section{Hasil dan Pembahasan}

\section{Hasil Penelitian}

Instrumen pengumpulan data yang digunakan dalam penelitian ini adalah angket kepribadian ekstrovert-introvert, Soal tes materi balok dan kubus,serta wawancara terstruktur berdasarkan tahapan prosedur newman. Angket kepribadian ekstrovertintrovert di isioleh 29peserta didik di kelas IX SMP N 12 Pontianak

Tabel 1.2 Hasil Angket Kepribadian Ekstrovert-Introvert

\begin{tabular}{|c|c|c|c|}
\hline No & Kode Siswa & Skor & Kecenderungan \\
\hline 1 & MDA & 9 & Ekstrovert \\
\hline 2 & AJN & 10 & Ekstrovert \\
\hline 3 & NAAZ & 14 & Ekstropvert \\
\hline 4 & RAS & 10 & Ekstrovert \\
\hline 5 & $\mathrm{MZ}$ & 10 & Ekstrovert \\
\hline 6 & SA & 12 & Ekstrovert \\
\hline 7 & RCA & 8 & Ekstrovert \\
\hline 8 & OS & 14 & Ekstrovert \\
\hline 9 & AS & 10 & Ekstrovert \\
\hline 10 & SBK & 11 & Intropvert \\
\hline 11 & MADH & 10 & Ekstrovert \\
\hline 12 & LTA & 13 & Introvert \\
\hline 13 & $\mathrm{ME}$ & 12 & Intropvert \\
\hline 14 & FSP & 10 & Ekstrovert \\
\hline 15 & AM & 14 & Introvert \\
\hline 16 & $\mathrm{PA}$ & 9 & Ekstrovert \\
\hline 17 & RAS & 10 & Ekstrovert \\
\hline 18 & $\mathrm{RS}$ & 10 & Ekstrovert \\
\hline 19 & DSP & 13 & Intropvert \\
\hline 20 & $\mathrm{SZ}$ & 10 & Intropvert \\
\hline 21 & AS & 9 & Ekstrovert \\
\hline 22 & MAP & 10 & Ekstrovert \\
\hline 23 & RAA & 10 & Intropvert \\
\hline 24 & YRA & 10 & Intropvert \\
\hline 25 & DIM & 9 & Ekstrovert \\
\hline 26 & WS & 9 & Ekstrovert \\
\hline 27 & AW & 9 & Ekstrovert \\
\hline 28 & $\mathrm{RR}$ & 9 & Ekstrovert \\
\hline
\end{tabular}


Dari Tabel 4.1 dapat dilihat peserta didik yang tergolong kepribadian esktrovertintrovert dengan skor yang berbeda, dari ke 29 peserta didik ada 3 orang peserta didik mendapat skor tertinggi berturut-turut yang masuk katagorikepribadiann ekstrovert yaitu : NAAZ, SA, dan OS. Sedangkan peesrta didik yang mendapat skor tertinggi yang masuk katogi kepribadian introvert yaitu: LTA, DSP dan AM.

Tabel 1.3 Data Kesalahan Jawaban Siswa Ekstrovert Tinggi

\begin{tabular}{|c|c|c|c|c|c|c|c|c|}
\hline \multirow[b]{2}{*}{ No } & \multirow{2}{*}{$\begin{array}{l}\text { Kode } \\
\text { Nama }\end{array}$} & \multirow{2}{*}{$\begin{array}{l}\text { Nomor } \\
\text { Soal }\end{array}$} & \multicolumn{5}{|c|}{$\begin{array}{c}\text { Kesalahan Berdasarkan Tipe } \\
\text { Newman }\end{array}$} & \multirow{2}{*}{$\begin{array}{c}\text { Kesalahan } \\
\text { yang } \\
\text { dilakukan } \\
\text { siswa } \\
\end{array}$} \\
\hline & & & $\mathbf{R}$ & $\mathrm{C}$ & $\mathbf{T}$ & $\mathbf{P}$ & $\mathbf{E}$ & \\
\hline \multirow[t]{4}{*}{1} & \multirow[t]{4}{*}{ NAAZ } & 1 & - & - & - & - & - & - \\
\hline & & 2 & - & - & - & $\sqrt{ }$ & $\sqrt{ }$ & $\mathrm{P}, \mathrm{E}$ \\
\hline & & 3 & - & - & $\sqrt{ }$ & $\sqrt{ }$ & $\sqrt{ }$ & $\mathrm{T}, \mathrm{P}, \mathrm{E}$ \\
\hline & & 4 & - & - & - & $\sqrt{ }$ & $\sqrt{ }$ & $\mathrm{P}, \mathrm{E}$ \\
\hline \multirow[t]{4}{*}{2} & SA & 1 & - & - & - & - & - & - \\
\hline & & 2 & - & - & - & - & $\sqrt{ }$ & $E$ \\
\hline & & 3 & - & - & $\sqrt{ }$ & - & $\sqrt{ }$ & $\mathrm{T}, \mathrm{E}$ \\
\hline & & 4 & - & - & - & $\sqrt{ }$ & $\sqrt{ }$ & $\mathrm{P}, \mathrm{E}$ \\
\hline \multirow[t]{4}{*}{3} & \multirow[t]{4}{*}{ OS } & 1 & - & - & - & - & - & - \\
\hline & & 2 & - & $\sqrt{ }$ & $\sqrt{ }$ & $\sqrt{ }$ & $\sqrt{ }$ & $\mathrm{C}, \mathrm{T}, \mathrm{P}, \mathrm{E}$ \\
\hline & & 3 & - & $\sqrt{ }$ & - & - & $\sqrt{ }$ & $\mathrm{C}, \mathrm{E}$ \\
\hline & & 4 & - & - & - & - & $\sqrt{ }$ & $\mathrm{E}$ \\
\hline
\end{tabular}

Tabel 1.4 Data Kesalahan Jawaban Siswa Introvert Tinggi

\begin{tabular}{|c|c|c|c|c|c|c|c|c|}
\hline \multirow[b]{2}{*}{ No } & \multirow{2}{*}{$\begin{array}{l}\text { Kode } \\
\text { Nama }\end{array}$} & \multirow{2}{*}{$\begin{array}{l}\text { Nomor } \\
\text { Soal }\end{array}$} & \multicolumn{5}{|c|}{$\begin{array}{c}\text { Kesalahan Berdasarkan Tipe } \\
\text { Newman }\end{array}$} & \multirow{2}{*}{$\begin{array}{c}\text { Kesalahan } \\
\text { yang } \\
\text { dilakukan } \\
\text { siswa }\end{array}$} \\
\hline & & & $\mathrm{R}$ & $\mathrm{C}$ & $\mathrm{T}$ & $\mathrm{P}$ & $\mathrm{E}$ & \\
\hline \multirow[t]{4}{*}{1} & \multirow[t]{4}{*}{ LTA } & 1 & - & - & - & - & - & - \\
\hline & & 2 & - & - & - & - & $\sqrt{ }$ & $E$ \\
\hline & & 3 & - & - & - & $\sqrt{ }$ & $\sqrt{ }$ & $\mathrm{E}$ \\
\hline & & 4 & - & - & - & $\sqrt{ }$ & $\sqrt{ }$ & $\mathrm{P}, \mathrm{E}$ \\
\hline \multirow[t]{4}{*}{2} & DSP & 1 & - & - & - & - & - & - \\
\hline & & 2 & - & - & - & - & $\sqrt{ }$ & $\mathrm{E}$ \\
\hline & & 3 & - & - & - & - & $\sqrt{ }$ & $E$ \\
\hline & & 4 & - & - & - & $\sqrt{ }$ & $\sqrt{ }$ & $\mathrm{P}, \mathrm{E}$ \\
\hline \multirow[t]{3}{*}{3} & \multirow[t]{3}{*}{$\mathrm{AM}$} & 1 & - & - & - & - & - & - \\
\hline & & 2 & - & - & - & $\sqrt{ }$ & $\sqrt{ }$ & $\mathrm{P}, \mathrm{E}$ \\
\hline & & 3 & - & $\sqrt{ }$ & $\sqrt{ }$ & $\sqrt{ }$ & $\sqrt{ }$ & $\mathrm{T}, \mathrm{P}, \mathrm{E}$ \\
\hline
\end{tabular}




\begin{tabular}{|l|l|l|l|l|l|l|l|l|}
\hline & & 4 & - & - & - & - & - & - \\
\hline
\end{tabular}

Keterangan :

1) $R:$ Kesalahan Membaca

2) $\mathrm{C}:$ Kesalahan Memahami Masalah

3) $\mathrm{T}$ : Kesalahan Transformasi

4) P : Kesalahan dalam Keterampilan Proses

5) E : Kesalahan Jawaban Akhir

6) - : Tidak ada kesalahan

7) $\sqrt{ }$ : Melakukan kesalahan

8) $\mathrm{X}$ : Tidak mengisi jawaban

\section{Pembahasan}

Berdasarkan hasil angket kepribadian ekstrovert-introvert yang diberikan kepada siswa kelas IX SMPN 12 Pontianak diperoleh fakta bahwa kelas IX SMPN 12 Pontianak tergolong kepribadian ekstrovert-introvert. Secara lengkap dikelas IX SMPN 12 Pontianak dapat dilihat gambar berikut ini:

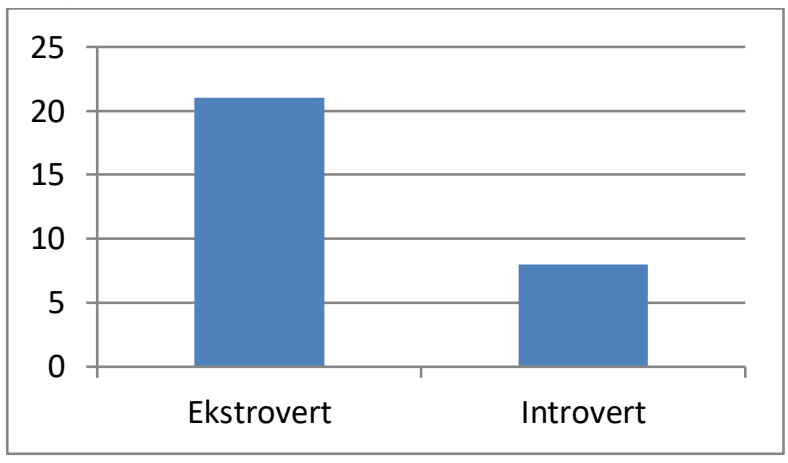

\section{Grafik 1.1 Kepribadian Siswa dikelas IX SMPN 12 Pontianak}

Jika dilihat dari gafik tersebut bahwa kepribadian yang lebih dominan adalah kepribadian ekstrovert. Hal ini sesuai dengan pengalaman peneliti, didapat kepribadain anak kebanyakkan ekstrovert. Salah satu contoh anak ekstrovert adalah anak yang aktif, suka berintraksi dengan orang banyak, tidak suka dengan pembelajaran yang lama, lebih suka bermain, sedangkan anak introvert anak yang pendiam, tidak banyak bicara, lebih suka waktu yang lama untuk menyelesaikan suatu masalah.

Materi balok dan kubus dijadikan bahan atau instrument dalam penelitian ini.Adapun sub-sub materinya adalah tentang mencari volume kubus dan balok, mencariluas permukaan kubus dan balok.Materi ini berkaitan dnegan kehidupan seharihari karna soal yang diberikan berbentuk cerita yang melibatkan benda yang ada disekitar siswa. Setelah di berikan tes ada beberapa kesalahan yang dilakukan siswa ekstovert-introvert. Kesalahan-kesalahan pada saat mengerjakan soal memang sering terjadi secara keseluruhan, dapat dilihat semua subjek penelitian melakukan kesalahan pada soal yang diberikan. Kesalahan yang dilakukan antara subjek satu dengan yang lainnya tidak selalu sama. Dari penelitian ini didapatkan hasil bahwa anak dengan kepribadian ekstrovert dalam proeses penyelesaian soal cerita materi balok dan kubus mengalami kesulitin berdasarkan prosedur Newman yaitu : (1) Memahami masalah; (2) 
Kesalahan Trasnformasi; (3) Kesalahan Keterampilan Proses; dan (4) Kesalahan Penulisan jawaban akhir. Sedangkan Sehingga anak dengan kepribadain introvert sering kali melakukan kesalahan dalam menyelesaikan soal cerita balok dan kubus berdasarkan prosedur Newman dalam penelitian ini ditemukan ada beberapa kesalahan yang rentan terjadi pada peserta didik dengan kepribadian introvert yaitu : (1) Kesalahan pada proses perhitungan dan (2) Kesalahan pada penulisan jawaban akhir atau kesimpulan.

Penelitian ini ternyata didukung dengan penelitian terdahulu yang dilakukakan oleh (Putri dkk, 2017); (Damayanti et al., 2020), yang meneliti siswa dengan kepribadian ekstrovert, dengan mengambil 35 siswa dengan diperoleh siswa yang katagori ekstrovert sebanyak 13 orang, penelitian tersebut mengatakan bahwa faktor penyebab siswa dengan kepribadian ekstrovert disebabkan oleh beberapa faktor, yaitu salah satunya saat mengerjakan soal terburu-buru, tidak teliti, kenginan ingin cepat selesai, kesalahan yang dilakukan siswa esktrovert tinggi dikatagorikan ke dalam prosedur Newman dan siswa esktrovert mengalami kesulitan memahami masalah (Comprehesion error), kesalahan transformasi (Transformation error), kesalahan dalam keterampilan proses (Process skill error), dan kesalahan jawaban akhir (Encoding error).

Hal ini juga sejalan dengan penelitian (Ita, 2012) hal ini untuk melihat apa saja kesalahan yang dilakukan peserta didik dengan kepribadian ekstrovert-introvert berdasarkan prosedur Newman, dimana sebanyak 30 siswa dan mengambil subjek ekstrovert katagori tinggi, katagori sedang dan katagori rendah, introvert tinggi, katagori sedang dan katagori rendah. Hasil penelitiannya diketahui bahwa : (1) peserta didik ekstrovert berkemampuan sedang lebih banyak dari siswa introvert berkemmapuan sedang; (2) siswa ekstrovert yang berkemampuan tinggi lebih sedikit dari pada siswa introvert berkemampuan tinggi; (3) siswa ekstrovert yang berkemampuan rendah lebih banyak dari pada siswa introvert berkampuan rendah; (4) siswa banyak mengalami kesulitan dalam menuliskan istilah matematika; (5) Siswa introvert dan ekstrovert yang berkemampuan rendah lebih banyak melakukan kesalahan dalam aspek transformasi dan kesalahan dalam keterampilan proses.

Sehingga dapat disimpulkan bahwa siswa dengan keprbadian esktrovert tinggi rata-rata melakukan kesalahan memahami masalah ( Comprehesion error), kesalahan transformasi (Transformation error), kesalahan dalam keterampilan proses (Process skill error), dan kesalahan jawaban akhir (Encoding error) dan berdasarkan hasil wawancara faktor yang mempengaruhi terjadinya kesalahan tersebut adalah karena terburu-buru, tidak teliti, tidak mengoreksi kembali, tidak hafal rumus, kemampuan berhitung rendah teruta pada pembagian.

Kesalahan peserta didik kepribadian ekstrovert berdasarkan prosedur newman.

Kesalahan Membaca (Reading Error); Kesalahan membaca (reading error) dilakukan oleh peserta didik yang berkepribadian ekstrovert tinggi untuk soal nomor 1 sampai 4 tidak ada.

Kesalahan Memahami Masalah (Comprehension Error); Kesalahan memahami masalah (comprehension error) dilakukan oleh peserta didik dengan kepribadian ekstrovert 
tinggi untuk soal nomor 1 tidak ada.Nomor 2 ada satu orang (OS) yang mengalami kesulitan memahami masalah.Nomor 3 ada satu orang (OS) yang mengalami kesulitan memahami masalah.Nomor 4 tidak ada yang melakukan kesalahan memahami masalah. Kesalahan dalam Transformasi (Transformation Error); Kesalahan dalam Transformasi (Transformation Error) dilakukan peserta didik dengan kepribadian ekstrovert tinggi untuk soal nomor 1 tidak peserta didik yang melakukan kesalahan transformasi, untuk soal nomor 2 terdapat satu orang peserta didik (OS) yang melakukan kesalahan transformasi, Soal nomor 3 terdapat dua orang peserta didik (NAAZ) dan (AS) yang mengalami kesulitan pada proses trasnformasi, nomor 4 tidak ada peserta didik yang melakukan kesalahan transformasi.

Kesalahan dalam Keterampilan Proses (Process Skill Error); Kesalahan dalam keterampilan proses (Process Skill Error) dilakukan peserta didik dengan kepribadian ekstrovert tinggi untuk soal nomor 1 tidak ada peserta didik yang melakukan kesalahan dalam keterampilan proses, pada nomor 2 terdapat dua orang peserta didik (NAAZ) dan (OS) yang melakukan kesalahan keterampilan proses, untuk soal nomor 3 terdapat satu orang peserta didik (NAAZ) yang mengalami kesulitan pada keterampilan proses, nomor 4 terdapat dua orang peserta didik (NAAZ) dan (AS) yang melakukan kesalahan keterampilan proses.

Kesalahan Jawaban Akhir (Encoding Error); Kesalahan Jawaban Akhir (Encoding Error) dilakukan oleh peserta didik dengan kepribadian ekstrovert tinggi. Untuk soal nomor 1 tidak ada yang mengalami kesulitan pada kesimpulan jawaban akhirnya, untuk nomor 2 sampai dengan 4 ketiga peserta didik (NAAZ), (AS), dan (OS) melakukan kesalahan jawaban akhir. Sehingga dapat disimpulkan bahwa peserta didik dengan kepribadian ekstrovert melakukan kesalahan pada proses penyelesaian soal cerita materi balok dan kubus yang berdasarkan prosedur Newman yaitu : (1) Memahami masalah; (2) Kesalahan Trasnformasi; (3) Kesalahan Keterampilan Proses; dan (4) Kesalahan Penulisan jawaban akhir.

\section{Kesalahan peserta didik kepribadian introvert berdasarkan prosedur newman.}

Kesalahan Membaca (Reading Error); Kesalahan membaca (reading error) dilakukan oleh peserta didik yang tergolong kepribadian introvert tinggi untuk soal nomor 1 sampai 4 tidak ada peserta didik yang melakukan kesalahan membaca.

Kesalahan Memahami Masalah (Comprehesion Error); Kesalahan memahami masalah (comprehension error) dilakukan oleh peserta didik yang tergolong kepribadian introvert tinggi untuk soal nomor 1 - 4 tidak ada dari mereka yang mengalami kesulitan dalam memahami masalah.

Kesalahan Transformasi (Transformation Error); Kesalahan transformasi (Transformation Error) dilakukan oleh peserta didik yang tergolong kepribadian introvert tinggi. Untuk soal nomor 1-4 tidak ada peserta didik yang melakukan kesalahan transformasi.

Kesalahan dalam Keterampilan Proses (Process Skill Error); Kesalahan dalam keterampilan proses (Process Skill Error) dilakukan oleh peserta didik yang tergolong kepribadian introvert tinggi. Untuk soal nomor 1 tidak ada peserta didik yang 
melakukan kesalahan dalam keterampilan proses, untuk soal nomor 2 tidak terdapat peserta didik yang melakukan kesalahan dalam keterampilan proses, untuk soal nomor 3 terdapat dua orang peserta didik (LTA) dan (AM) yang mengalami kesulitan dalam keterampilan proses, untuk soal nomor 4 terdapat dua orang peserta didik (LTA) dan (DSP) yang melakukan kesalahan dalam keterampilan proses.

Kesalahan Jawaban Akhir (Encoding Error); Kesalahan jawaban akhir (Encoding Error) dilakukan oleh peserta didik yang tergolong kepribadian introvert tinggi. Untuk soal nomor 1 tidak ada peserta didik yang melakukan kesalahan jawaban akhir, untuk soal nomor 2 terdapat 3 orang peserta didik (LTA), (DSP) dan (AM) mengalami kesulitan pada jawaban akhir, nomor 3 terdapat tiga orang peserta didik (LTA), (DSP), dan (AM) yang mengalami kesulitan atau kesalahan jawaban akhir, untuk soal nomor 4 terdapat dua orang peserta didik (LTA) dan (DSP) yang melakukan kesalahan jawaban akhir. Sehingga dapat disimpulkan bahwa peserta didik dengan kepribadain introvert sering kali melakukan kesalahan dalam menyelesaikan soal cerita balok dan kubus berdasarkan prosedur Newman dalam penelitian ini ditemukan kesalahan atau tambatan yang sering dialami peserta didik dengan kepribadian introvert sebagai berikut: (1) Kesalahan Keterampilan Proses dan (2) Kesalahan Jawaban Akhir.

\section{Kesimpulan dan Saran Kesimpulan}

Dari pemaparan diatas maka dapat disimpulkan kesalahan yang dilakukan peserta didik dengan kepribadian ekstrovert-introvert di SMPN 12 Pontianak tidak ada perbedaan yang terlalu spesifik kebanyakan kesalahan yang dilakukan hampir sama. Adapun kesimpulan dari rumusan masalah khusus, adalah sebagai berikut : 1) Peserta didik Ekstrovert rata-rata melakukan kesalahan dalam menyelesaikan soal cerita materi balok dan kubus berdasarkan prosedur Newman yaitu : kesalahan memahami masalah (Comprehension error), kesalahan transformasi (Transformation error), kesalahan keterampilan proses (Process skill error) dan kesalahan jawaban akhir (Encoding error). 2) Peserta didik Introvert rata-rata mengalami hambatan padasaat menyelesaikan soal cerita materi balok dan kubus berdasarkan prosedur Newman yaitu : Kesalahan keterampilan proses (Process skill error)dan kesalahan jawaban akhir(Encoding error). 3) Perbedaan kesalahan jawaban yang tampak dilakukan peserta didik kepribadian ekstrovert dengan peserta didik introvert dalam menyelesaikan soal cerita materi balok dan kubus berdasarkan prosedur Newman yaitu pada kesalahan memahami masalah dan kesalahan tranformasi, karna jika dilihat dari hasil dan pembahasaan peserta didik dengan kepribadian ektrovert masih banyak melakukan kesalahan memahami mahasalah dan kesalahan tranformasi di bandingkan dengan peserta didik kepribadian introvert.

\section{Saran}

Dari hasil penelitian terdapat kelemahan-kelemahan dalam penelitian ini, peneliti memberikan saran sebagai berikut: 1) Bagi peserta didik, sebaiknya peserta didik membaca soal cerita dengan teliti dan memahami isi dari soal tersebut sehingga 
mempermudah peserta didik untuk membuat membuat model matematika, menentukan strategi dan melakukan prosedur yang benar. Selain itu, sebaiknya peserta didik diberi banyak latihan-latihan soal cerita yang banyak membahas tentang materi kubus dan balok, yaitu tentang mencari luas permukaan, volume dan menentukan panjang, lebar dan tinggi, 2) Bagi guru, sebaiknya dalam mengajar materi balok dan kubus dalam soal cerita mengambil kejadian yang ada disekitar lingkungan peserta didik. 3) Unutuk penelitian selanjutnya yang akan melakukan penelitian serupa dengan ini disarankan menggunakan materi yang berbeda dengan soal cerita kontekstual yang ada dilingkungan siswa, objek yang diambil sebaiknya satu kelas supaya dapat dilihat perbedaan kesalahan yang dilakukan peserta didik kepribadian ekstrovert-introvert.

\section{Referensi}

Abdurrahman, M. (2012). Peserta didik Berkesulitan Belajar.Jakarta : Rineka Cipta.

Arikunto, Suharsimi. (2013). Prosedur Penelitian. Jakarta: Rineka Cipta

Hardi Suyitno. (2014). Filsafat Matematika. Semarang : Universitas Negeri Semarang, hal.177.

NCTM.(2000). Principles and Standardscfor School Mathematics. Tersedia di www.nctm.org.

Permendikbud Nomor 22 Tahun 2016 Tentang Standar Proses Pendidikan dan Menengah.

Pratikipong, Natcha dan Nakamura, Satoshi. (2006). Analysis of Mathematics Performance of Grade Five Students in Thailand Using Newman Procedure. Journal of International Cooperation in Education.

Damayanti, S. D., Hartoyo, A., \& Suratman, D. (2020). Kesalahan Siswa Dalam Menyelesaikan Soal Statistika Tipe Higher Order Thinking Skills. Jurnal AlphaEuclidEdu, 1(2), 59. https://doi.org/10.26418/ja.v1i2.41642

Hartoyo, A. (2012). Eksplorasi Etnomatematika Pada Budaya Masyarakat Dayak Perbatasan Indonesia-Malaysia Kabupaten Sanggau Kalbar. 13(1), 14-23.

Saputro, M., Yadi, A., \& Dona, F. (2015). Faktor-Faktor yang Mempengaruhi Prestasi Belajar (Studi Korelasi Pada Mahasiswa Pendidikan Matematika IKIP PGRI Pontianak). Jurnal Pendidikan Informatika Dan Sains, 4(2), 233-246.

Sarwono, E., Yusmin, E., \& Suratman, D. (2017). Pengaruh Model Pembelajaran Kooperatif Tipe STAD.

Ulya, D. (2020). Pengembangan Bahan Ajar Interaktif Untuk. 1(2), 162-171.

Zaman, S dan Abdilah, S. (2009). MBTI (Mayyers-Brrggs Type Indikator). Jakarta: Visimedia 